\author{
Aleksandra Rabowska \\ Uniwersytet im. Adama Mickiewicza w Poznaniu
}

\title{
Blogosfera - jak Internet zmienił komunikację i marketing?
}

\begin{abstract}
Streszczenie
Podjęte tu rozważania skupiają się wokół analizy przebiegu ewolucji nowych technik przekazywania informacji, z położeniem szczególnego nacisku na przemiany u dziedzinie komunikowania się. Celem artykułu jest zaprezentowanie procesu rozwoju systemu komunikacji za pośrednictuem Internetu, a u szczególności za pośrednictuem blogów. W badaniach podjęto się próby przeanalizowania przeobrażania się blogosfery na tle jej upłyuu na procesy komunikacyjne oraz komunikację marketingową. Oceniono socjologiczne zjawiska przeobrażania się Internetu, a szczególną uwagę badauczą skoncentrowano na dynamicznej adaptacji nowych metod i form przekazu oferowanych w blogosferze w korelacji do mechanizmów zachowań społeczeństwa sieciowego.
\end{abstract}

Słowa kluczowe: blogosfera, blogi, Internet, komunikacja, marketing, marketing internetowy.

\section{Blogosphere - how the Internet has changed communication and marketing? (based on the thesis: The usage of online marketing tools in a Polish culinary blogosphere)}

\begin{abstract}
The idea of this research is to analyze the evolution of the new information transmission techniques, involving the special emphasis on changes in the field of communication. What is more, the development of the blogosphere is presented on the background of its influence on communication process. The purpose of this study is to identify relationships between development of blogosphere, communication and marketing communication. This research provides valuable information regarding the sociological phenomenon of transformation of the Internet. The overall approach is focused on dynamic adaptation of new methods and new form of communication offered on blogosphere in correlation to the mechanisms of social behavior network.
\end{abstract}

Key words: blogosphere, blogs, Internet, communication, marketing, online marketing.

\section{Wprowadzenie}

Czy jesteśmy u stanie określić, jakie zmiany zachowań i stylu życia uspółczesnego konsumenta niesie za sobą rozwój globalnej sieci? Czy korzystanie z Internetu stało się już nawykiem konsumentów? Czy firmy zmieniają przez to model podejścia do biznesu i komunikacji marketingowej? I ureszcie, czy charakter twórczości blogera może być 
realnym przykładem realizacji założeń biznesowych wynikających z masowego charakteru Internetu?

Rozważania nad digitalizacją uszelkich obszarów życia pozwoliły autorce na zaobserwowanie zjawisk, które są wyjaśnieniem odejścia od jednokierunkouych środków masowego przekazu i realizacji jednych z podstawowych funkcji Internetu interaktywności i partycypacji w mediach, gdzie nadawcy i odbiorcy są jednocześnie twórcami. Internet jest $w$ tym wymiarze miejscem, gdzie o wiele swobodniej niż $\mathrm{w}$ świecie rzeczywistym można dostosowywać odpowiednie strategie marketingowe do odrębnych segmentów rynku.

Żyjemy w czasach, kiedy postęp techniczny pozwala nam na coraz łatuiejsze zaspokajanie niemal każdej potrzeby - w takim wymiarze może się zatem rodzić pytanie o współczesną istotę i tryb funkcjonowania marketingu. Zadaniem marketingu już od momentu jego poustania było zuiększenie sprzedaży, więc jak on działa w tej chuili? Co się dzieje, kiedy u dobie tak dynamicznych zmian, rynki tak bardzo nasycone są różnorodnością produktów i usług? Czy przedsiębiorstua są w stanie nadążyć za suoimi klientami?

Aby przedsiębiorstuo mogło teraz realnie ubiegać się o klientów, powinno liczyć się z tym, że musi mieć w zanadrzu ogromną paletę przymiotów, za pomocą których może faktycznie konkurować z innymi firmami. Stosowanie tradycyjnych instrumentów marketingu mix, czyli ceny, produktu, dystrybucji oraz reklamy i promocji, to dzisiaj kropla u marketingowym morzu działań. Na arenę wchodzi teraz marketing internetowy, a wraz z nim jego mechanizmy wykorzystywane między innymi w blogosferze.

\section{"Internet is the message", czyli internet $\mathrm{i}$ jego wkład w system komunikacji}

Marshall McLuhan był jednym z pieruszych teoretyków nouych mediów, który przewidywał, że świat kształtowany przez konsekwencje, jakie dało wprowadzenie druku na papierze, u przyszłości będzie ewoluował dzięki mediom elektronicznym. Jego teorię skraca się często do jednego i tym samym jego najbardziej słynnego zdania: „The medium is the message” ${ }^{1}$, które przetłumaczone na polski mogłoby najprościej brzmieć: „Przekaźnik jest przekazem”. Koncepcja ta zakłada, że charakterystyka danego środka społecznego przekazu bardziej upływa na zbiorową świadomość niż sama treść przez niego uytworzona, a środek przekazu nie tylko kształtuje treści, ale także zmienia odbiorcę. Dla kanadyjskiego badacza media były jakoby przedłużeniem ludzkiego ciała i zmysłów, a uszelkie nowe możliwości i pola działania człowieka tuorzą nowy model komunikacji społecznej. Zbiorowa świadomość, która utworzyła się jako

1 M. McLuhan, Wybór pism, tłum. K. Jakubowicz, Wydawnictuo Artystyczne i Filmowe, Warszawa 1975, s. 10. 
następstuo ciągłego poszerzania możliwości technologicznych, jest najbardziej zauważalna w przypadku wirtualnej przestrzeni komunikacyjnej - Internetu.

Internet to jedyne w swoim rodzaju medium masowego przekazu, które okazało się niezwykle rozwojowe na płaszczyźnie socjologicznej, ponieważ w bardzo szybkim tempie zaczęło wpływać na wiele aspektów życia społecznego. W tym duchu Petr Hejl tak oto zdefiniował Internet: „policentryczny system socjokulturowy, który posiada granicę przez różnicę między byciem a niebyciem jego użytkounikiem”2. Można zatem powiedzieć, że Internet jest niczym organizm, jego zaś pełnowartościoue części składowe poustają niezależnie od siebie, tworząc jedną wielką cyberprzestrzeń, do której należy społeczeństwo sieciowe.

Nawiązując do użytkowników Internetu, a u szerszym ujęciu do społeczeństwa sieciowego, nie sposób nie uspomnieć Manuela Castellsa, który swą koncepcję społeczeństua sieciowego rozpropagował już w pierwszej połowie lat 90. ubiegłego wieku. Jego teoria jest niejako wstępem do badań nad zmianami w dziedzinach gospodarki informacyjnej i społeczeństwa informacyjnego, gdzie cyfrowe technologie dominują nad uszelkimi dziedzinami życia człowieka. W takim społeczeństwie dochodzi do dezintegracji tradycyjnie ukształtowanych grup społecznych, bowiem rozwój technologii niesie za sobą nieoduracalny już proces homogenizowania całego świata w jedną globalną wioskę. Jest to procedura, której świadkiem jest każdy z nas, ponieważ dynamiczna informatyzacja stanowi nieodłączny element funkcjonowania uspółczesnego świata. Tym samym Internet przestaje być wyłącznie siecią, a staje się ogromnym narzędziem porozumiewania się ludzi, które w dużym stopniu tworzy rzeczywistość społeczną ${ }^{3}$ Biorąc pod uwagę, że żyjemy u świecie, gdzie każdą informację, niezależnie od jej zawartości, możemy zamienić na jej wersję u zapisie zero-jedynkowym, stajemy przed możliwością „przekodowania całego uniwersum komunikacji”4. Sieć stworzyła wirtualny obszar komunikacyjny i odpowiada za kształtowanie się nieznanych jeszcze 20 lat temu elementów okoliczności komunikacyjnych.

Ewolucja oblicza Internetu sprowadza się do tego, że jego użytkownicy uspółtworzą treści u nim zawarte, a co nawet ważniejsze, uspółdecydują o ich eksponowaniu. Internauci to także aktywni odbiorcy, którzy coraz częściej korzystają z tradycyjnych mediów za pośrednictwem sieci - czytają prasę, słuchają radia, oglądają ulubiony program telewizyjny, czy robią zakupy ${ }^{5}$. Jednostronność komunikowania charakteryzująca media analogowe, w Internecie ustępuje miejsca wielostronności. Daje ona odbiorcy nie tylko możliwość biernego użytkowania WWW, lecz róunież aktywnego uczestnictua $\mathrm{w}$ jego tworzeniu.

2 M. Graszewicz, D. Lewiński, Wstęp do systemowej teorii Internetu [w:] Nowe media we wspótczesnym społeczeństwie, red. M. Jeziński, A. Seklecka, Ł. Wojtkouski, Wydawnictwo Naukoue Uniwersytetu im. Mikołaja Kopernika, Toruń 2011, s. 13.

3 J. Adamczyk, Internet jako narzędzie komunikacji marketingowej [w:] Komunikacja marketingowa - kształtowanie społeczeństwa konsumpcyjnego?, red. T. Goban-Klas, Wyższa Szkoła Handlowa w Radomiu, Radom 2006, s. 369.

4 Ibidem, s. 19.

5 D. Kaznouski, Nowy marketing w Internecie, Difin, Warszawa 2007, s. 19. 
Cyberspołeczeństuo zaczęło aktyunie korzystać z zasobów sieci w momencie, gdy zaczęły poustawać pierwsze serwisy usługowe, tj. sklepy internetowe czy komunikatory. To utedy ułaśnie na arenę hipermedialnego środowiska komputerowego weszła komunikacja marketingowa ${ }^{6}$. To, że zasięg Internetu stale się zwiększa, jest jednym z podstawouych dowodów na to, że rola sieci wciąż rośnie. Rewolucja cyfrowa zmieniła uszystko - sposoby tworzenia, szukania i przechowywania treści, a także krytyki i dzielenia się informacjami.

Według Jana W. Wiktora rok dla Internetu to siedem lat w rozwoju świata niecybernetycznego? ${ }^{7}$. Internet, jak żadne inne z istniejących dotychczas mediów, oferuje niezwykle obszerną platformę do prowadzenia i zintegrowania $u$ jednym miejscu działań marketingowych, ale $\mathrm{w}$ warunkach ciągłych zmian narzędzia e-marketingu wciąż się modyfikująa

\section{Jak Internet zmienił proces komunikacji firm z konsumentami?}

Zwiększający się zasięg globalnej sieci komputerowej niesie za sobą diametralne zmiany zachowań i stylu życia uspółczesnego konsumenta. Internet nie jest już tylko wirtualnym światem, dostępnym dla ograniczonego grona odbiorców. Teraz stał się niemal miejscem życia wielu użytkouników. To do Internetu przenoszą się kontakty międzyludzkie, to tu zawiera się nowe znajomości, przez co zmienił się sposób, w jaki się komunikujemy. W Internecie obejrzymy film, przeczytamy książkę, spraudzimy rozkład jazdy komunikacji miejskiej, zarezerwujemy bilety na spektakl teatralny, a z pomocą kursora zwiedzimy najdalsze zakątki świata. Ale co najważniejsze, wszystkie wymienione rzeczy nie są już tylko dostępne wirtualnie. Teraz każdą z nich możemy kupić, albowiem do Internetu przeniosły się uszelkie możliwe transakcje handlowe. Niewątpliwie znajduje to swoje odzwierciedlenie w nowych postawach zakupowych konsumentów, a także odmiennych sposobach konsumpcji. Wcale nie dziwi więc fakt, że tak naprawdę trudno dziś znaleźć firmę, która nie ma ułasnej strony internetowej. Internet jawi się bowiem nie tylko jako najszersze i wręcz nieograniczone źródło informacji, ale także jako platforma niesamowitych możliwości rozwoju przedsiębiorczości. I podobnie jak wzrasta liczba internautów, tak samo wzrasta liczba podmiotów, które wykorzystują sieć w działaniach marketingouych ${ }^{9}$.

Marketing internetowy, zwany także marketingiem online lub e-marketingiem, może zostać prosto zdefiniouany przez stuierdzenie, że sprowadza się on do osiągania

6 J. Adamczyk, op. cit., s. 367.

7 J.W. Wiktor, Promocja. System komunikacji przedsiębiorstwa z rynkiem, Wydawnictwo Naukowe PWN, Warszawa 2001, s. 233.

8 J. Adamczyk, op. cit., s. 368.

9 D. Kaznowski, Nowy marketing, VFP Communications Ltd., Warszawa 2008, s. 10-11. 
celów marketingowych poprzez zastosowanie technologii komunikacji cyfrowej ${ }^{10}$. W takim ujęciu marketing internetowy odnosi się do perspektywy, według której Internet może być używany w połączeniu z innymi tradycyjnymi nośnikami marketingu. Marketing jest koncepcją takiego zarządzania firmą, która pozwala jej na przetrwanie i rozwijanie się $w$ warunkach konkurencji rynkowej dzięki umiejętności spełniania potrzeb konsumentów ${ }^{11}$. Internet staje się w tym rozumieniu miejscem, gdzie można realizować strategie marketingowe przystosowane do potrzeb innych i tak naprawdę bardzo skonkretyzowanych segmentów rynku. Głównym motywem stosowania Internetu przez firmy wydaje się chęć osiągania przychodów z tytułu dostarczania konsumentom określonych wartości ${ }^{12}$. Można tym samym powiedzieć, że rynki indywidualizują się, bowiem składają się z ludzi, a nie ze zuykłych sektorów demograficznych, jak w przypadku tradycyjnego marketingu.

Sam Bill Gates miał stwierdzić, że Internet jest jak Eldorado XXI wieku - i nie mylił się. Za potęgą Internetu stoi pewien niezaprzeczalny fakt - jest to rynek, który liczy już teraz prawie 3,6 miliarda użytkouników na całym świecie ${ }^{13}$, którzy mogą kupować przez 24 godziny na dobę, przez 365 dni u roku. Żadne inne media nie dadzą przedsiębiorcy szansy na dotarcie do tak wielkiej liczby potencjalnych klientów. Dodatkowo Internet skraca czas niezbędny do przeprowadzenia transakcji oraz dotarcia produktu do klienta, co niejednokrotnie skłania do ponawiania zakupów ${ }^{14}$. W tym świetle marketing internetowy jawi się jako następstwo konkretnych kroków, które pomogą w zidentyfikowaniu potencjalnego konsumenta - dzieje się to dzięki niebagatelnym i potężnym środkom oferowanym przez globalną sieć komputerową. Rozwój Internetu spowodował powstanie prawdziwego e-rynku, czyli takiego, który jest „wirtualną sferą, gdzie produkty i usługi istnieją jako cyfrowe informacje” ${ }^{\text {15. Według }}$ Janusza Wielkiego taki rynek charakteryzuje się: uszechobecnością, łatwością dostępu do informacji oraz niskimi kosztami transakcji ${ }^{16}$.

Na wirtualnym rynku mamy do czynienia z handlem wirtualnym, zwanym elektronicznym lub e-commerce. „W węższym znaczeniu jest to sposób sprzedawania i kupowania produktów i usług z wykorzystaniem środków elektronicznych za pośred-

10 D. Chaffe, E-Business and E-Commerce Management: Strategy, Implementation and Practice, FT Prentice Hall, Harlow, England 2007, s. 339.

11 S. Kaczmarczyk, R. Pałgan, Marketing $w$ przedsiębiorstwie. Ujęcie zarządcze $i$ systemowe z przykładami, ODDK, Gdańsk 2008, s. 15.

12 A. Bajdak, Internet $w$ marketingu, Polskie Wydawnictwo Ekonomiczne, Warszawa 2003, s. 139.

13 Liczba internautów liczona na podstawie Internet World Stats uynosiła w lutym 2013 roku 2,4 miliarda osób; w czerucu 2016 roku liczba ta uzrosła do 3,6 miliarda osób, http://uww.internetworldstats.com/stats.htm [dostęp: 6.10.2016].

14 J. Wielki, Elektroniczny marketing poprzez Internet, PWN, Warszawa 2000, s. 119-120.

15 J.F. Rayport, J.J. Sviokla, Managing in the Marketplace, „Harvard Business Review”, listopad-grudzień 1994, nr 72(6), s. 141-150, cyt. za: E. Frąckiewicz, Marketing internetowy, Wydawnictuo Naukoue PWN, Warszawa 2006, s. 24.

16 J. Wielki, op. cit., s. 56. 
nictuem Internetu"17. Jeśli chcemy jednak spojrzeć na to zjawisko szerzej, warto wspomnieć, że za handlem elektronicznym kryją się tak naprawdę wszelkie transakcje handlowe, zawierane za pomocą sieci teleinformatycznych, połączone z dokonywaniem płatności za oferowane produkty i usługi. Te transakcje dokonywane są oczywiście bez konieczności bezpośredniego kontaktu między stronami. Dynamiczny rozwój e-handlu zdaje się naturalnym następstwem stylu życia, jaki przyjmuje teraz większość konsumentów. Za kupowaniem i sprzedawaniem przez Internet stoją nie tylko wygoda, ale także oszczędność czasu, tak ważna we wciąż galopującym świecie.

Kamil Bartczak uskazał, że najistotniejszym bodźcem narzucającym przyspieszenie wzrostu wartości rynku u sieci jest postępująca digitalizacja zakupów. Wciąż obserwujemy eskalację liczby internautów, ale co w tym momencie nawet ważniejsze, z sieci korzystamy intensyuniej niż kiedykoluiek ucześniej - i to głównie dzięki urządzeniom mobilnym. Tak bardzo dynamiczny rozwój kanałów mobilnych łączy się z tym, że umożliwiają one dostęp do informacji z dowolnego miejsca, w którym w tym momencie użytkownik się znajduje. Jest to ogromny atut dla przedsiębiorstw, które wykorzystają szansę kontaktu z klientami korzystającymi ze smartfonów, zanim zrobi to konkurencja - zułaszcza w sytuacji, gdy już teraz możemy kupować i płacić za towary dzięki bankowym aplikacjom mobilnym ${ }^{18}$.

Internet charakteryzuje się ogromnym potencjałem opracowania i zapewnienia odpowiednich wartości dla klienta. Według Ewy Frąckiewicz użytkowanie Internetu w tych celach wspomaga realizację tzw. działań „pięciu C”, które dzięki uwzględnieniu specyfiki marketingu internetowego są nowym ujęciem marketingu-mix. „Pięć C” możemy uznać za cechy Internetu, które wskazują jak e-marketing może i powinien być wykorzystany przez wszystkie podmioty obecne na rynku. Są to:

I. Coordination, czyli zadania w sferze koordynacji procesów decyzyjnych w przedsiębiorstuie.

II. Commerce, czyli obrót handlowy pozwalający na obniżenie kosztów transakcji i poszerzenie rynków docelowych.

III. Community, czyli budowanie uspólnoty, co jest łatwiejsze u Internecie niż w śuiecie rzeczywistym.

IV. Content, czyli prezentacja treści informacyjnych, które w Internecie mogą tak naprawdę dotyczyć nieograniczonej liczby tematów.

V. Communication, czyli sposoby komunikacji, które pozwalają na wymianę komunikatów elektronicznych w czasie rzeczywistym z dowolną liczbą odbiorców ${ }^{19}$.

17 E. Frąckiewicz, op. cit., s. 113.

18 Raport interaktywnie.com: E-commerce, http://interaktywnie.com/biznes/artykuly/raporty-interaktyunie-com/raport-interaktyunie-com-e-commerce-247357, s. 38-39 [dostęp: 14.02.2014].

19 E. Frąckiewicz, op. cit., s. 17. 


\section{Charakterystyka komunikacji marketingowej w Internecie}

Na czym polega siła e-marketingu? Co sprawiło, że to dzięki Internetowi wiele firm zapeuniło sobie rynkowy sukces? Potężny potencjał firm inwestujących w handel w Internecie i wykorzystujących narzędzia e-marketingu sprowadza się głównie do tego, że ten rodzaj działalności praktycznie nie ma żadnych ograniczeń. Dziś dotarcie z reklamą produktów i promocją firmy jest możliwe do i z każdego zakątka świata. Tak naprawdę wszystko zależy od tego, czy firma potrafi odpowiednio dobrać narzędzia i wykorzystać uszystkie możliwości, jakie niesie za sobą e-marketing.

Działania marketingowe opierają się na obserwacji rynku i podjęciu odpowiednich decyzji. Przy tempie zachodzących na rynku zmian i wciąż rosnącej konkurencji coraz trudniejsze okazuje się osiągnięcie zamierzonych przez przedsiębiorstwo celów. W takich warunkach Internet okazuje się dla firm prowadzących działalność gospodarczą efektywnym narzędziem, służącym nie tylko do zarządzania relacjami z klientami czy dostawcami, lecz również badaniem otoczenia marketingowego ${ }^{20}$.

Interaktywność, szybkość, brak granic, globalny i masowy charakter Internetu sprawiają, że utworzył się swoisty model biznesu i komunikacji z otoczeniem marketingouym. Konsument ma dziś możliwość bez wychodzenia z domu, znalezienia różnorodnych informacji, pochodzących z wielorakich źródeł, przy czym czas czy miejsce nie stanowią dla niego żadnej granicy w gromadzeniu, selekcjonowaniu czy przetwarzaniu informacji. Konsument ma możliwość pełnej kontroli nad procesem realizacji transakcji, przy czym oszczędza czas. To samo tyczy się przedsiębiorcy, który teraz dodatkowo może z łatwością dostosować się do potrzeb odbiorców, poznać swoich klientów znacznie lepiej niż dotychczas. Te przedsiębiorstwa, które używają Internetu w swojej działalności, mogą oferować suoim klientom cenną wartość dodatkową wygodę zakupu, czyli dostępu do oferty, możliwości złożenia i realizacji zamówienia, nieograniczonej ani czasem, ani miejscem. W Internecie klient zyskuje jedyną w swoim rodzaju możliwość dostępu do informacji o produktach i usługach oferowanych przez firmy i może te oferty swobodnie porównywać i finalnie dokonać najbardziej optymalnego dla siebie wyboru.

Przedsiębiorstwa, które chcą osiągnąć sukces, często przenoszą część swojej działalności do Internetu, a od momentu, kiedy zaczęto wykorzystywać sieć w celach komercyjnych, nieustannie wzrasta liczba firm korzystających z Internetu w działaniach marketingowych. Internet stał się atrakcyjny nie tylko ze względu na swoją siłę przebicia, lecz także ze względu na relatywnie niskie koszty i możliwość stosowania strategii zindywidualizowanych, czyli takich, w których działania są dostosowywane do oczekiwań konsumentów. Takie podejście zwiększa satysfakcję klienta i wzmacnia lub buduje jego lojalność wobec firmy. Dominik Kaznowski trafnie stuierdzil, że „gospodarka internetowa przesuwa ciężar komunikacji z kuszenia atrakcyjną ofertą na

${ }^{20}$ Ibidem, s. 19. 
rozwiązywanie potrzeb i problemów klienta" ${ }^{21}$ - dzieje się to w momencie, kiedy wzrost znaczenia informacji powoduje, że klient samoistnie i samodzielnie odkrywa swoje potrzeby. Internet jest $w$ tym wymiarze miejscem, gdzie o wiele swobodniej niż $\mathrm{u}$ świecie rzeczywistym można dostosowywać odpowiednie strategie marketingoue do odrębnych segmentów rynku. Żeby dostosować przekaz do potrzeb konkretnych jednostek, rezygnuje się z komunikacji skierowanej do masowego odbiorcy, którą zastępują komunikaty konstytuowane na podstawie wiedzy na temat tego, co myśli, wie, odczuwa i czyni odbiorca ${ }^{22}$. Takie zjawisko odbywa się przede wszystkim w momencie zawierania transakcji, kiedy to rejestrując swój zakup, konsument przestaje być tylko anonimowym klientem. Dzięki temu przedsiębiorstua działające w Internecie muszą być zorientowane na komunikację partnerską ze swoimi klientami, dzięki której jest budowana pewna społeczność czy też zaangażowanie podkreślające relacje pomiędzy konsumentem a marką. Wpływa to wyraźnie na model biznesowy, który jest zorientowany na kreowanie lojalnych klientów, a nie tylko jednorazowego aktu sprzedaży $y^{23}$.

Firmy coraz chętniej i śmielej korzystają z sieci, a z roku na rok rosną budżety przeznaczone na komunikację marek w Internecie. Dzieje się tak, ponieważ uzmysłowiono sobie, że jego prawidłowe uykorzystanie pozytywnie wpływa na funkcjonowanie przedsiębiorstwa, a poprzez ustanawianie jedynego w swoim rodzaju kanału komunikacji z klientem tworzy się jednocześnie dodatkouy kanał zbytu. Bowiem za e-marketingiem stoi nie tylko usprawnianie kanału komunikacji firmy z klientem - działania marketingu online mają też na celu promocję, wzmacnianie wizerunku organizacji. Dlatego właśnie te przedsiębiorstua, które chcą osiągnąć sukces, często przenoszą część swojej działalności do Internetu lub tworzą od podstaw całkowicie nowe biznesy, oparte wyłącznie na działalności w sieci. Kaznouski wskazał, że „niski próg wejścia do biznesu sieciowego sprawia, że w sieci działa bardzo duża liczba podmiotów"24. Z marketingowego punktu widzenia Internet jest bodźcem, który popycha kolejne sektory gospodarki oraz biznesu, by konkurowały ze sobą o coraz to skuteczniejsze sposoby zabiegania o klientów. Należy jednak pamiętać, że jakość uymiany informacji, jaką zyskuje się dzięki wykorzystaniu sieci, u znaczący sposób zmienia organizację przedsiębiorstua - dotyczy to przede wszystkim etapów zaopatrzenia, zbytu towaru i produkcji ${ }^{25}$. Wykorzystanie Internetu zmienia także sposób funkcjonowania firm od zaplecza, a dzięki przyspieszeniu wymiany informacji wpływa na wysoką koordynację pracy.

21 D. Kaznowski, op. cit., s. 43.

22 A. Ryłko-Kurpieuska, Reklama jako sztuka powtórzeń, Novae Res, Gdynia 2016, s. 341. Autorka podaje $u$ książce wiele przykładów zindywidualizowanego podejścia do konsumenta, które jest widoczne zarówno w mediach nowych, jak i zmieniających się pod wpływem komunikacji w mediach cyfrowych nośników tradycyjnych. Por. ibidem, s. 243-405.

23 Ibidem.

24 D. Kaznouski, op. cit., s. 35.

25 E. Frąckiewicz, op. cit., s. 91. 


\section{Dlaczego blogosfera? Blogi jako płaszczyzna wykorzystania działań marketingowych}

$\mathrm{Na}$ arenie marketingu internetowego od kilku lat obserwujemy ogromne zmiany. Nieustannie się on rozwija, bez przerwy wyłaniają się nowe rozwiązania i narzędzia, które przedsiębiorcy śmiało uykorzystują do promocji suojego przedsiębiorstua u sieci. Z punktu widzenia przedsiębiorstu zintegrowana komunikacja marketingowa odgrywa bardzo znaczącą rolę, bowiem wpływa na postawy konsumentów, które są ważnym składnikiem wizerunku marki. Nie dziwi więc stwierdzenie, że marketing ogółem to ciągłe pytanie o nowe rozwiązania i nieprzerwane poszukiwania innowacyjnych sposobów na wyróżnienie się od konkurencji, nabudowanie relacji z klientami i na podbijanie nowych rynków. Dla tej analizy szczególne znaczenie ma pewien trend, który został dostrzeżony przez działy marketingowe - coraz częściej do działań w Internecie uykorzystuje się blogi.

Od kilku lat polska blogosfera ewoluuje i zyskuje coraz bardziej na popularności. Jest wiarygodnym źródłem informacji oraz medium opiniotwórczym już nie tylko wśród określonych grup zainteresowań i w środowisku specjalistów, lecz zaczyna również odgrywać istotną rolę w znacznie szerszej, masowej skali. Ostatnimi czasy coraz więcej firm uwzględnia w swoich działaniach uspółpracę z blogerami, a kampanie z ich udziałem są prowadzone w zasadzie na każdego typu blogach: modowych, lifestylowych, parentingowych, technologicznych, kulinarnych. O takich kampaniach słyszy się coraz częściej, bowiem wiele firm dostrzegło potencjał tych witryn, które bez wątpienia charakteryzują się większą niż w przypadku normalnych stron internetowych liczbą interakcji, wciąż uydłużającym się czasem, który internauci spędzają na blogu, rosnącą z miesiąca na miesiąc unikalną liczbą użytkouników odwiedzających blog. Co dodatkowo zachęca firmy do nawiązywania uspółpracy, to fakt, iż zaczęto zauważać, że dzisiejszy bloger to prawdziuy i szeroko rozpoznawalny lider opiniii ${ }^{26}$. W ostatnich latach część blogerów awansowała bowiem do tej grupy i przez to znaleźli się oni na marketingouym celowniku tych, którzy chcą wykorzystać potencjał promocyjny tkwiący w blogach.

Jak wynika z raportu pt. Blogerzy w Polsce 2013 - znajomość, wizerunek, znaczenie, który skupia się na analizie polskiej blogosfery z perspektywy internautów, połowa z nich czyta blogi co najmniej raz na miesiąc, a już co trzeci respondent kieruje się rekomendacjami z bloga podczas zakupów ${ }^{27}$. Jak zauważyła Dominika Maison:

Bloger staje się interesującym połączeniem «zuykłego człowieka», który sam z ułasnej inicjatywy przekazuje innym informacje o suoich doświadczeniach (często konsumenckich),

${ }^{26}$ A. Przeździęk, Rozwój blogów w Polsce i wspótpraca z blogerami [u:] Marketing w sieci podstawowe zagadnienia, inspiracje i przykłady, Kraków 2011, http://www.marketingwsieci-szkolenia.pl/upload/MWS-WSE.pdf, s. 36 [dostęp: 17.03.2014].

${ }^{27}$ Blogerzy w Polsce 2013 - znajomość, wizerunek, znaczenie, http://pbi.org.pl/aktualnosci/Blogerzy\%20w\%20Polsce\%202013\%20(18kwi13).pdf [dostęp: 17.03.2014]. 
a róunocześnie jest często liderem opinii, gdyż zazuyczaj zna się na czymś trochę lepiej niż inni i ułaśnie tą wiedzą próbuje się dzielić ze suoimi czytelnikami ${ }^{28}$.

Maison podkreśliła, że u tym wymiarze blogi są niezuykle silnie oddziałującym narzędziem bezpośredniej komunikacji między konsumentami, a gros czytających blogi chętnie korzysta z wiedzy przekazywanej na nich przez ich autorów.

Oddziaływanie blogerów na konsumentów ujawnia się częściej jako umiejętność zniechęcania ich do zakupu jakiegoś produktu - większa jest bowiem szansa, że internauta pod wypływem negatywnego recenzji nie zdecyduje się na zakup lub też oduróci się od firmy, niż kupi coś po przeczytaniu promujących opinii ${ }^{29}$. Andrzej Garapich słusznie przy tym zauważył, że blogosfera choć ma dzisiaj większy zasięg niż uszystkie media uznawane za wiarygodne, tj. tradycyjne wydania gazet czy telewizje informacyjne, to i tak „dopiero kilka lat temu blogerów uznano za pełnoprawnych uczestników branży internetowej i potraktowano blogosferę jako wiarygodną przestrzeń reklamową" ${ }^{30}$. W związku z tym można śmiało stwierdzić, że dziś marketerzy nie zastanawiają się, czy współpracować z blogerem, a raczej pytają, jak z nim współpracować, by osiągnąć wymierne efekty.

Adam Przeździęk uskazał, że polskie blogi kojarzone z jaskrawymi „blogaskami” nastolatek już dawno odeszły w zapomnienie, teraz w blogosferze królują pasjonaci i hobbyści, celebryci i politycy, a co ważne, także i eksperci, którzy dzielą się z internautami swoją wiedzą $w$ danej dziedzinie. Blogi przeszły tym samym niesamowitą metamorfozę, począuszy od osobistych pamiętników po blogi specjalistyczne, które mogą z powodzeniem konkurować ze standardowymi serwisami tematycznymi, a niektóre blogi, ze względu na swoją ogromną popularność oraz ciągłe poszerzanie opisywanej tematyki, ewoluowały w stronę serwisów branżowych ${ }^{31}$. Topowe blogi w Polsce są niezależnymi serwisami, a ich swoboda, charakteryzowana cenioną przez blogeróu ułasną przestrzenią w Internecie, jest znamienna, jeśli dochodzimy do ich uspółpracy biznesowej z innymi podmiotami. Na polskim rynku współdziałanie na linii bloger-firma traktowane jest uciąż jako przedsięuzięcie nieszablonowe, mimo to coraz chętniej i częściej stosowane.

W tym wymiarze niezuykle ciekawe są wyniki badania pt. Blogosfera 2012. Badanie opinii marketerów na temat wizerunku blogerów, reklamy na blogach i przyszłości działań reklamowych ${ }^{32}$. Listę blogerów objętych tą analizą skompletowano tak, by każda kategoria tematyczna blogów (kulinarna, technologiczna, modowa

\footnotetext{
28 Ibidem, s. 8.

${ }^{29}$ Ibidem, s. 16.

30 Ibidem, s. 13.

31 A. Przeździęk, op. cit., s. 32.

32 Pełen raport dostępny jest za pomocą funkcji „Pay with a tweet or facebook” - osoba chcąca go przeczytać będzie musiała „zapłacić” za niego automatycznie umieszczaną notką na Tuitterze albo postem na Facebooku, http://hatalska.com/blogosfera-2012-pierusze-badanie-polskiej-blogosfery-z-perspektywy-reklamodawcow/ [dostęp: 17.03.2014].
} 
etc.) była reprezentowana w miarę możliwości przez co najmniej dwóch reprezentantów. Za ostatecznym wyborem konkretnych blogerów stała także liczba zrealizowanych projektów marketingowych lub jego popularność wśród internautów. Respondentami tego badania były agencje reklamowe, domy mediowe, agencje PR oraz przedstawiciele klientów, którzy mieli już okazję uspółpracować z blogerami - ten fakt czyni to badanie pieruszą na gruncie polskim analizą ujauniającą, jak blogi i blogerów postrzegają reklamodawcy. Opisywane tu badanie zostało zrealizowane przez Instytut Millward Brown, a raport z niego podzielono na dwie części - pierwsza charakteryzuje blogera jako markę osobistą, druga zaś odpowiada na pytania, jak reklamodawcy postrzegają swoje doświadczenia w uspółpracy reklamowej z blogerami oraz jakie przewidują perspektywy rozwoju tej formy kooperacji w przyszłości. Co znamienne, niemal uszyscy respondenci stwierdzili, że rezultaty uspółpracy mają realne przełożenie na ich biznes i u związku z tym wierzą, że udział blogów w kampaniach reklamouych jest zjawiskiem, które będzie się w Polsce coraz bardziej rozpouszechniać.

Wspomniane badanie ma niezwykłe znaczenie dla uświadomienia sobie, że polscy blogerzy stają się marką samą w sobie - nie tylko internauci kojarzą ich po pseudonimie lub z nazwiska, ale także w branży, którą reprezentują, blogerów uznaje się za specjalistów, a coraz więcej osób po prostu wie, czym zajmuje się dany bloger i ma na jego temat wyrobioną konkretną opinię. Relacje blogerów z otoczeniem można rozumieć jako relacje z grupą użytkouników, z którymi podejmują oni uspólne działania blogi są tym miejscem w sieci, które jest zorientowane na użytkownika i które charakteryzowane jest dynamicznymi interakcjami pomiędzy członkami internetowej społeczności. Pojawiające się u badaniu Blogosfera 2012... opinie marketerów na temat blogerów pokazały, że są to osoby uznawane za wiarygodne, opiniotwórcze, zaznajomione z tematem, o którym piszą, zaangażowane oraz posiadające grupę lojalnych czytelników. Ta ostatnia cecha jest niezaprzeczalnie ważna z perspektywy firm, chcących uspółpracować z blogerami, albowiem pozwala to marce dotrzeć do konkretnej grupy docelowej ${ }^{33}$.

Nie oznacza to oczywiście, że uskazywano, iż blogerzy mają uyłącznie pozytywne atrybuty, ponieważ wielu z nich ma kłopoty z brakiem profesjonalizmu, terminowością i myśleniem czysto biznesowym. „Kuintesencję typouych dla marketingu wątpliwości stanowić może jedna z wypowiedzi cytowanych w raporcie: «blogerzy nie myślą jak marketerzy, ale jak konsumenci»”34, podkreślił Mariusz Staniszeuski. Sprowadza się to do tego, że blogerzy często nie rozumieją zagadnień związanych z marką, a przejście na stronę „profesjonalnej komunikacji medialnej” przy pozostaniu reprezentantem własnych poglądów i jednocześnie wpływowym rzecznikiem grup konsumenckich udaje się $\mathrm{w}$ zasadzie tylko czołowym blogerom. Ponadto respondenci wskazali, że blogerzy potrafią być nieprzewidywalni oraz zadufani w sobie. Pomimo to

33 Ibidem, s. 24.

34 Ibidem, s. 17. 
prawie uszyscy ankietowani uyrazili co najmniej umiarkowane zadowolenie ze współpracy z blogerami i jednocześnie byli zdania, że była ona opłacalna.

Kolejna część raportu z badania Blogosfera 2012..., dotycząca szczegółóu współpracy na linii bloger-firma, unaoczniła dwa ważne i warte przeanalizowania trendy. Po pierusze, reklamodaucy stuierdzili, że coraz chętniej uspółpracują z niszowymi blogerami niż z tymi najbardziej znanymi. Co ciekawe, nie jest to dyktowane mniejszymi oczekiwaniami finansouymi mniej popularnych blogów, a raczej tym, iż marketerzy doskonale wiedzą, że przy wykorzystaniu takich blogów można łatwiej dotrzeć z przekazem do konkretnej grupy docelowej. Blog jako „twór komunikacji elektronicznej" ${ }^{35}$ jest u tym wymiarze niezastąpionym środkiem komunikacji.

„Marketerzy nieustannie poszukują miejsc, gdzie kontakt konsumenta z ich marką będzie jeden do jeden" 36 , a co za tym idzie ich przekaz reklamowy nie będzie pojawiał się w sąsiedztuie innych, choć niekoniecznie konkurencyjnych kampanii, jak to bywa w przypadku blogów cieszących się popularnością. Z biznesowego punktu widzenia taka sytuacja nie przynosi markom większych korzyści lub uręcz czyni im szkodę. Po drugie, z raportu wynika, że współpraca z blogerami ,jest warta wydanych na ten cel pieniędzy" "7. Tym samym badanie potwierdziło, że korzyści wynikające z działań w blogosferze są mierzalne i przekładają się na konkretne efekty.

Tomek Tomczyk stwierdził, że tak naprawdę największą wartością blogów nie są one same, ale blogerzy ułaśnie. Wysunął on też wyjątkowo śmiałą hipotezę, że u niedalekiej przyszłości:

najlepiej zarabiać będą blogerzy, którzy nie tylko reklamują na blogu daną markę, ale sami są reklamą tej marki. Bloger stanie się uyższą formą celebryty, bo celebryta jest tylko biernym nadaucą jakiejś treści. [...] Dziś blogerzy to nie tylko pisarze-amatorzy. To liderzy opinii, mający dziesiątki i setki tysięcy czytelników, pojawiający się we wszystkich środkach masowego przekazu. Od melin po pałace. Od kurników po tropikalne wyspy. Mają więcej czytelników od najpopularniejszych dziennikarzy i pisarzy u tym kraju, więcej niż niejeden program $\mathrm{w}$ telewizji. I u przeciwieństwie do dziennikarzy, którzy muszą prezentować u miarę obiektywne opinie, my prezentujemy wyłącznie subiektywne”38.

W tym momencie należałoby przeanalizować, dlaczego ostatnie lata przyniosły części blogujących (na wszystkie tematy) awans do szeroko rozpoznawalnych liderów opinii. Liderami opinii będą ci konsumenci, którzy mają wpływ na opinie innych i przy tym kształtują ich upodobania zakupowe. Blog staje się niejako narzędziem, które swojego autora kreuje jako specjalistę $w$ danej dziedzinie ${ }^{39}$. W internetowym śuiecie takie

35 G. Stachyra, Blog - tekst elektroniczny [w:] Język w internecie: antologia, red. M. Kita, I. Loewe, Wydawnictwo Uniwersytetu Śląskiego, Katowice 2016, s. 128.

36 Ibidem, s. 31.

37 Ibidem.

38 T. Tomczyk, Bloger, wydaje.pl, Katowice 2012, s. 218-220.

39 P. Szews, Mikroblog - odmiana blogu czy oddzielny gatunek? [w:] Język w internecie: antologia, op. cit., s. 145. 
osoby często nazywa się influencerami ${ }^{40}$, trendsetterami ${ }^{41}$, a także niestety błędnie coolhunterami $^{42}$. Ze względu na ich wiedzę, umiejętności komunikacyjne oraz umiejętności perswazyjne, takie osoby istotnie oddziałują na otoczenie konsumenckie. Według badań przeprowadzonych przez Paula Mardsena z London School of Economics w społeczeństwie mamy zaledwie 10\% liderów opinii, jednak ich siła jest o tyle wielka, że mogą oni upływać na opinie i decyzje niemalże każdego z pozostałych 90\% konsumentów ${ }^{43}$. Oczywiście takie dane statystyczne potwierdzają się i w rzeczywistości dziś nietrudno zauważyć, jak wielką rolę odgrywają osoby, które naśladujemy, ponieważ chcemy pretendować do ciągłego poduyższania swojego statusu społecznego, chcemy porównywać się z najlepszymi, najlepiej ubranymi czy prowadzącymi najzdrowszy tryb życia.

Warto tu także uspomnieć o bardzo znanym eksperymencie przeprowadzonym w latach 60. XX wieku przez Stanleya Milgrama, który już wtedy wykazał, że większość z nas bezwiednie podporządkouuje się autorytetom ${ }^{44}$. To właśnie autorytet lideróu opinii sprawia, że są oni tak chętnie uykorzystywani przez firmy, agencje reklamowe i całe sztaby marketingowców jako żywe narzędzie do wspierania komunikacji z innymi konsumentami. I choć eksperyment miał odpowiadać na pytanie o powody ślepego posłuszeństwa wobec zbrodniczych rozkazów, to jego wyniki, analizowane na gruncie ogólnych założeń dotyczących ludzkiego zachowania, są aktualne po dziś dzień.

\section{Podsumowanie}

Przedmiotem zainteresowania niniejszej pracy były zjawiska dotyczące rewolucyjnych zmian w systemie komunikacji, które są dyktowane rozwojem Internetu. W świetle przeprowadzonych obserwacji sieć jawi się bowiem jako jedyne w swoim rodzaju medium masouego przekazu, które w bardzo szybkim tempie zaczęło wpływać na wiele aspektów życia społecznego.

${ }^{40}$ Influencer to rzeczownik utworzony od angielskiego czasounika: to influence, tłumaczonego jako: upływać, oddziaływać, warunkować.

41 Trendsetter to rzeczownik utworzony z angielskiej frazy czasownikowej: to set a trend, oznaczającej osobę kreującą nowe mody, style.

42 Coolhunter to profesja, która poustała na gruncie amerykańskim, lecz powoli ukracza i na polskie podwórko. W przeciwieństuie do trendsettera, coolhunter jest osobą, która zajmuje się przewidywaniem nowych trendów konsumentów. Jej zadaniem jest obserwowanie danej grupy społecznej (często z wykorzystaniem internetowych forów dyskusyjnych, blogów, serwisów społecznościowych) i przez analizę ich zachowań wychwytywanie ciekawych koncepcji i pomysłów.

${ }^{43}$ M. Siejak, Filary rekomendacji, http://www.marketing.org.pl/index.php/go=2/act=2/aid= m4cfb8912cf063/ [dostęp: 11.03.2014].

${ }_{4}$ Jak u skrócie podsumował sam Milgram u książce Posłuszeństwo wobec autorytetu (1974, wyd. pol. tłum. M. Hołda, Wydawnictuo WAM, Kraków 2008): „Głównym wynikiem tej serii badań jest stuierdzenie krańcouej skłonności dorosłych ludzi do uczynienia niemalże uszystkiego, by tylko spełnić polecenie autorytetu". 
Przy tempie zachodzących na rynku zmian i wciąż rosnącej konkurencji przedsiębiorstwa praktycznie nie mogą już funkcjonować bez potencjału oferowanego im przez Internet. Dla firm prowadzących działalność gospodarczą Internet jest efektywnym narzędziem, służącym nie tylko do zarządzania relacjami z klientami czy dostawcami, lecz również do badania otoczenia marketingowego i osiągania założonych celów marketingowych. Wykorzystanie narzędzi marketingu interaktywnego pociąga także za sobą istotne znaczenie dla handlu wirtualnego i procesów komercjalizacji Internetu. Firmy inwestujące $w$ sprzedaż $w$ Internecie oraz wykorzystujące narzędzia e-marketingu mają przed sobą obiecujące perspektywy rozwoju, ponieważ wdrażane przez nich rozwiązania wyznaczają nowe standardy rynkowe.

Ponadto ewolucja oblicza Internetu pokazuje, że jego użytkounicy uspółtworzą treści u nim zawarte, a co nawet ważniejsze, uspółdecydują o ich eksponowaniu. Blogi jawią się tutaj jako platforma do prowadzenia dyskusji przy równoczesnym ominięciu tradycyjnej i często krępującej sytuacji komunikacyjnej. W przypadku blogów duże znaczenie odgrywa bezpośrednia, otwarta forma komunikacji, która z reguły jest przeciustawieniem klasycznego języka specjalistycznego. Bezpośredniość komunikacji i identyfikowanie się odbiorców z autorami blogów sprawiają, że relacje budowane między nimi są znacznie bliższe niż u przypadku tradycyjnych form mediów analogowych. Pozorna anonimowość sprzyja zabieganiu uczestników wirtualnych aktów mowy, do uychodzenia poza ramy i nawiązywania specyficznych relacji, które dają im sposobność do aktywnego budowania przekazu, a także jego percepcji i przesłania.

O sile i zasięgu blogera świadczy grono wiernych i powracających regularnie czytelników, a wykorzystanie różnorodnych narzędzi marketingu internetowego sprawia, że wizerunek blogera utrwala się w oczach jego odbiorców, a jemu samemu ułatwia wsłuchiwanie się w potrzeby swojej wirtualnej publiczności.

\section{Bibliografia}

Adamczyk J., Internet jako narzędzie komunikacji marketingowej [w:] Komunikacja marketingowa - kształtowanie społeczeństwa konsumpcyjnego?, red. T. Goban-Klas, Wyższa Szkoła Handlowa w Radomiu, Radom 2006.

Bajdak A., Internet w marketingu, Polskie Wydawnictwo Ekonomiczne, Warszawa 2003.

Blogerzy w Polsce 2013 - znajomość, wizerunek, znaczenie, http://pbi.org.pl/aktualnosci/Blogerzy\%20w\%20Polsce\%202013\%20(18kwi13).pdf [dostęp: 17.03.2014].

Chaffe D., E-Business and E-Commerce Management: Strategy, Implementation and Practice, FT Prentice Hall, Harlow, England 2007.

Frąckiewicz E., Marketing internetowy, Wydawnictuo Naukowe PWN, Warszawa 2006.

Graszewicz M., Lewiński D., Wstęp do systemowej teorii Internetu [w:] Nowe media we współczesnym społeczeństwie, red. M. Jeziński, A. Seklecka, Ł. Wojtkouski, Wydawnictwo Naukowe Uniwersytetu im. Mikołaja Kopernika, Toruń 2011.

Hatalska N., Blogosfera 2012, http://hatalska.com/blogosfera-2012-pierusze-badanie-polskiej-blogosfery-z-perspektywy-reklamodawcow/ [dostęp: 17.03.2014]. 
Internet World Stats, http://wuw.internetworldstats.com/stats.htm [dostęp: 6.10.2016].

Kaczmarczyk S., Pałgan R., Marketing $w$ przedsiębiorstwie. Ujęcie zarządcze $i$ systemowe z przykładami, ODDK, Gdańsk 2008.

Kaznowski D., Nowy marketing, VFP Communications Ltd., Warszawa 2008.

Kaznouski D., Nowy marketing w Internecie, Difin, Warszawa 2007.

McLuhan M., Wybór pism, tłum. K. Jakubowicz, Wydawnictwo Artystyczne i Filmowe, Warszawa 1975.

Milgram S., Posłuszeństwo wobec autorytetu, tłum. M. Hołda, Wydawnictwo WAM, Kraków 2008.

Przeździęk A., Rozwój blogów w Polsce i wspótpraca z blogerami [w:] Marketing w sieci-podstawowe zagadnienia, inspiracje i przykłady, Kraków 2011, http://www.marketingusieci-szkolenia.pl/upload/MWS-WSE.pdf [dostęp: 17.03.2014].

Raport interaktywnie.com: E-commerce, http://interaktywnie.com/biznes/artykuly/raporty-interaktyunie-com/raport-interaktyunie-com-e-commerce-247357 [dostęp: 14.02.2014].

Ryłko-Kurpieuska A., Reklama jako sztuka powtórzeń, Novae Res, Gdynia 2016.

Siejak M., Filary rekomendacji, http://www.marketing.org.pl/index.php/go=2/act=2/aid=m [dostęp: 11.03.2014].

Stachyra G., Blog - tekst elektroniczny [w:] Język w internecie: antologia, red. M. Kita, I. Loewe, Wydaunictwo Uniwersytetu Śląskiego, Katowice 2016.

Szews P., Mikroblog - odmiana blogu czy oddzielny gatunek? [w:] Język w internecie: antologia, red. M. Kita, I. Loewe, Wydawnictwo Uniwersytetu Śląskiego, Katowice 2016.

Tomczyk T., Bloger, wydaje.pl, Katowice 2012.

Wielki J., Elektroniczny marketing poprzez Internet, Wydawnictuo Naukowe PWN, Warszawa 2000.

Wiktor J.W., Promocja. System komunikacji przedsiębiorstwa z rynkiem, Wydawnictwo Naukowe PWN, Warszawa 2001. 